\title{
Influence of Work Environment Toward Turnover Intention with Motivation and Job Satisfaction as Intervening Variables in PT. TSA
}

\author{
Ikhwan Tri Wiliyanto $^{1 *}$, I Ketut Sudiarditha ${ }^{2}$, Corry Yohana ${ }^{3}$ \\ Universitas Negeri Jakarta, Jakarta, Indonesia \\ email: ${ }^{{ }^{*}}$ itrwiliyanto@gmail.com \\ ${ }^{2}$ ketut.sudiarditha@unj.ac.id, ${ }^{3}$ corryyohana@unj.ac.id
}

\begin{abstract}
This research aims to examine wher work environment influences employee turnover intentions at PT TSA. In addition, this study also examines Job Satisfaction and Motivation as an intervening variable as mediating role toward influence of Work Environment on employee turnover intentions. In some literature found that variable Job Satisfaction and Motivation variables cannot mediate influence of Work Environment on Turnover Intention, refore researchers want to reconfirm it once more.This study uses entire population of 256 workers at PT TSA outlets as respondents. In this study re are 5 (five) hyposes to test direct effect and 2 (two) hyposes to test indirect effect through analysis techniques using Structural Equation Modeling (SEM) with AMOS 22 software. $\mathrm{n}$ in mediation test researcher uses Sobel test to test significance of effect of mediation found in research model. results of hyposis testing state that all hyposes made on research model are accePTed.
\end{abstract}

Keywords - Turnover Intention, Work Environment, Job Satisfaction, Motivation, Intervening, Structural Equation Modeling (SEM), Sobel Test

\section{INTRODUCTION}

Turnover Intention related to one important asset in a company, namely human resources. For companies, human resources are a key factor in providing services, sources of innovation and creativity through ir thinking and this can improve company performance and can be a competitive advantage for company. Human resources that have lasted a long time in company means that re is an investment value that is invested in form of a recruitment process, training, job placement and or similar activities. Based on importance of value of human resources in a company, management must strive to maintain employee loyalty in order to survive in company or to avoid employee turnover in company.

Turnover intention is a very dominant determinant that gives influences towards company's operational activities. Turnover intentions are formed from desires that exist within an employee's individual, which arises within him desire to leave company, related to discrepancies with his work, environment, leadership, and or matters related to his work that make him already feel uncomfortable at being at company. Some factors that are thought to influence turnover intention are job satisfaction, work motivation and work environment.

IJoASER,Volume 3, Issue 1, March, 2020

DOI: 10.33648/ijoaser.v3i1.42

Copyriht: STAI Al-Furqan Makassar,Indonesia

Content License: CC-BY-SA

Received: 26 Jan |Revised: 17 Feb 2020 | Accepted: 05 March 2020 
Job satisfaction is a measure of how far company can meet expectations of its employees relating to various aspects of work and position. Employees who can meet ir expectations at work will certainly feel happy and satisfied so that ir performance will always be stable or even increased. Employees with high levels of job satisfaction have positive feelings about job, while someone who is dissatisfied has negative feelings about job. Employees who have a sense of satisfaction with ir work tend to perform better. Employees who are satisfied with ir work will certainly minimize ir turnover intention.

Anor factor that is quite influential on turnover intention is work motivation. Work motivation is one of psychological characteristics of humans that contributes to one's level of commitment, including factors that cause, channel and sustain human behavior in a particular direction that is done. Employees who work in companies certainly need motivation from organization where y work. High motivation tends to strengn employee morale at work, improve work quality and strengn employee commitment to company so that it will not be reflected in his intention to leave work (turnover intention).

Turnover intention is influenced by many factors, one of which is a work environment with a negative and significant influence on variable turnover intention. This means that better working environment, individual employee will reject turnover intention in him no matter how much attractive or companies. Many studies also show that work motivation has a negative and significant effect on intention to quit. It can also be interpreted that higher motivation of employees working in company today y will reject desire to leave mselves from company. Anor factor is job satisfaction which has an effect on turnover intention wherein many studies have shown that job satisfaction has a significant negative effect on turnover intention. This also means that if employees get high job satisfaction re will be no intention to resign from company.

Previous research that made a reference in research conducted by author is a study from [1].purpose of this study is to analyze effect of job satisfaction, job environment on turnover intention by using internal motivation as an intervening variable. Turnover intention indicators used are job search, thinking about leaving and dreaming of a career in anor company. internal motivation indicator used is Utilizing potential, learning new and creative things. While job environment indicator used is relationship between employees, work atmosphere and employee work facilities [1].

One company that is experiencing turnover problems is PT. TSA which will be object of research for turnover in company in period of 2016-2018 is still quite large with an average ranging between 118 - 159 employees. Every year turnover at PT. TSA also experienced a very large increase at closing time, which ranged from 1424 - 1920 employees. This problem certainly has an impact on company performance so it needs to be explored cause of high turnover of company. Based on descriPTion that has been stated, researcher is interested in conducting research with title " Influence Of Work Environment Toward Turnover Intention With Motivation And Job Satisfaction As Intervening Variables In PT. TSA". 


\section{METHOD}

Data collection techniques include: Observation, Interview and Documentation. Data obtained from the results of the study were processed using descriptive qualitative data analysis. This study wants to investigate the effect of work environment on turnover intention that mediated by job satisfaction and work motivation at PT. TSA (Bread Talk) in Jakarta area. $n$ research subjects are PT. TSA (Bread Talk) in Jakarta area. object under study was Bread Talk employees in Jakarta region. $\mathrm{n}$ research time is scheduled to last for six months from July 2019 to January 2020. population in this study is all employees who have worked for more than 1 year PT. TSA (Bread Talk) in Jakarta area which is spread out in outlets in DKI Jakarta area.

Population in this study were employees of PT. TSA (Breadtalk) scattered in DKI Jakarta area totaling 256 people, in this study using saturated or census sampling. According to Sugiyono (2010: 124) "Saturation sampling is a sampling technique if all members of population are used as research samples." So sampling in this study is equal to population of 256 respondents.

Research method used in this research is a quantitative method. According to Sugiyono quantitative methods can be interpreted as a research method based on philosophy of positivism, used to examine specific populations or samples, data collection using research instruments, quantitative / statistical data analysis with aim of testing hyposes that have been set [2]. $n$ data collection using questionnaires on a scale of 1-5 in stages starting from strongly disagree to strongly agree.

Data analysis technique in this study uses Structural Equation Modeling (SEM) analysis method, which is a set of tools and techniques that can simultaneously solve all equations in a causal model that consists of variables manifested (observed) or latent (not observed), [3]. advantage of SEM is being able to test complex research models simultaneously so that it is more appropriate in ory testing. On or hand SEM can also analyze model as a whole so that it can help researchers to conclude wher model according to ory is supported by data. SEM is also able to analyze variables that cannot be measured directly and can calculate errors in its measurement. In this study, researchers used variables that cannot be measured directly, so researchers must use several indicators. $n$, measurement errors can also be calculated using SEM so that it can increase statistical estimates and validity. Measurement errors occur because re are rarely variables that can be measured perfectly. This is due to imperfections in operationalizing variables and / or inaccurate answers from respondents [4]. 


\section{RESULTS}

Respondents in this study were all employees of PT. TSA (Breadtalk) spread throughout DKI Jakarta. The questionnaire was distributed totaling 256. Based on table 1 there are several criteria in the demographic sample in this study which are summarized in table 1 below.

Table 1. Demographics Profile of Respondents

\begin{tabular}{|c|c|c|c|}
\hline Criteria & Group & Frequency & Persentage \\
\hline \multirow[t]{3}{*}{ Status } & Married & 82 & $32 \%$ \\
\hline & Not married & 172 & $67.2 \%$ \\
\hline & Widow/widower & 2 & $0.8 \%$ \\
\hline \multirow[t]{4}{*}{ Age } & $18-25$ years & 140 & $54,7 \%$ \\
\hline & $26-35$ years & 88 & $34.4 \%$ \\
\hline & $36-45$ years & 22 & $8.6 \%$ \\
\hline & $46-55$ years & 6 & $2.3 \%$ \\
\hline \multirow{5}{*}{$\begin{array}{c}\text { Length of } \\
\text { Work }\end{array}$} & $1-1,5$ years & 67 & $26.2 \%$ \\
\hline & $1,6-2$ years & 79 & $30.9 \%$ \\
\hline & $2,1-2,5$ years & 37 & $14.5 \%$ \\
\hline & $2,6-3$ years & 25 & $9.8 \%$ \\
\hline & $>3$ years & 48 & $18.8 \%$ \\
\hline \multirow{2}{*}{$\begin{array}{c}\text { Gender } \\
\text { Type }\end{array}$} & Man & 177 & $69.1 \%$ \\
\hline & Woman & 79 & $30.9 \%$ \\
\hline \multirow{3}{*}{$\begin{array}{c}\text { Education } \\
\text { Level }\end{array}$} & High school & 223 & $87.1 \%$ \\
\hline & Diploma 3 & 9 & $3.5 \%$ \\
\hline & Bachelor & 24 & $9.4 \%$ \\
\hline
\end{tabular}

Source: Data output of research results

Based on the prerequisite tests conducted to test the indicators used in the research model, we can seen that results obtained are all the indicators used to test the model meet the required criteria. The reliability test using the AVE and $\mathrm{CR}$ values based on test results on the indicator instrument shows the AVE value is more than 0.5 and the CR value has exceeded 0.7 which means that overall it has fulfilled validity and has been reliable. Thus, the analysis process can be continued at the next stage, which is the prerequisite test phase of SEM analysis. Then the results of testing the validity using the EFA 
showed no cross loading between indicator items in the tested variables, besides that the EFA test results showed that no pattern matrix was formed. This shows that the tested indicator items can be tested at a later stage.

CFA model depicted in Figure 2 is a full CFA research model. Based on table 2 states that the GoF criteria have been met as seen. This shows that the CFA model can be further analyzed because it has a probability score (P) greater than 0.05 which is equal to 0.095 and all scores in the goodness of fit criteria have been met. A summary of the GoF criteria can be seen in the table below. next process is to create a path analysis model.

Table 2 Godness of Fit (GoF) CFA Model

\begin{tabular}{|r|c|c|c|c|}
\hline No. & Goodness of Fit & Cut off Value & Hasil Analisis & Evaluasi Model \\
\hline 1. & Chi Square & Sekecil mungkin & 351,446 & Fit \\
\hline 2. & Probability & $\geq 0,05$ & 0,095 & Fit \\
\hline 3. & RMSEA & $\leq 0,08$ & 0,020 & Fit \\
\hline 4. & GFI & $\geq 0,9$ & 0,910 & Fit \\
\hline 5. & AGFI & $\geq 0,9$ & 0,892 & Fit \\
\hline 6. & CMIN/DF & $\leq 2,00$ & 1,105 & Fit \\
\hline 7. & TLI & $\geq 0,9$ & 0,996 & Fit \\
\hline 8. & CFI & $\geq 0,9$ & 0,992 & \\
\hline
\end{tabular}

Source: Output Amos (2020)

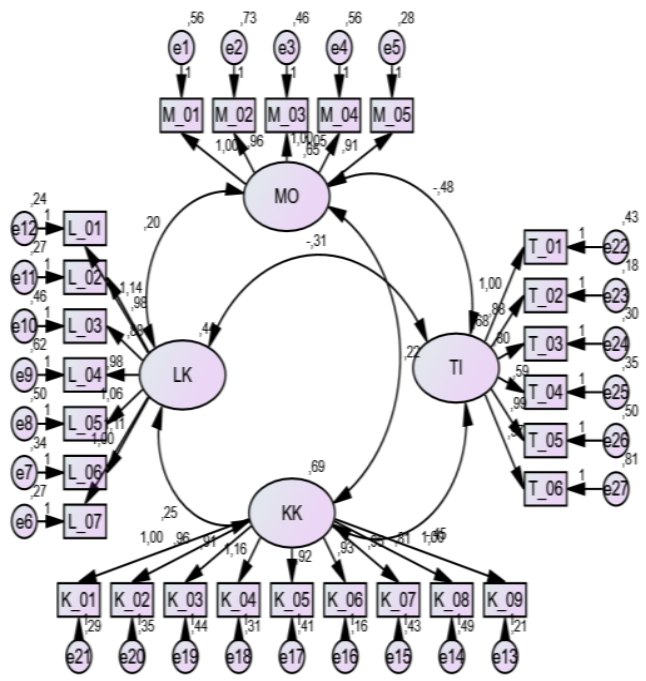

Figure 2. Confirmatory Factor Analysis Full Model

IJoASER, Volume 3, Issue 1, March, 2020

DOI: 10.33648/ijoaser.v3i1.42

Copyriht: STAI AI-Furqan Makassar,Indonesia

Content License: CC-BY-SA

Received: 26 Jan |Revised: 17 Feb 2020 | Accepted: 05 March 2020 
In figure three is a hypothesis testing model in which all proposed hypotheses are tested with that model. Before knowing the hypothesis test performed, the model must first meet the GoF criteria. In figure three it can be seen that all GoF criteria have been met, this can be represented at a probability value of 0.063 which is above 0.05 . This shows that the hypothesized model created can be further analyzed.

For the next stage is hypothesis suitability test which done by looking at the $t$-value, which is the value of the critical ratio (CR) in the regression weight with the provisions if the value $\geq 1.96$ or $\leq-1.96$, then the research hypothesis is accePTed with a probability value of 0.05 or with a *** sign that indicates a value less than 0.01 or close to zero. After testing the model, the next step is to look at the regression weight value to find out whether the tested hypothesis is accePTed or not. In table 3 there are the results of calculations from the hypothesis test which states relationship between variables tested in these research. In results of these calculations stated that all tested hypotheses were can be accePTed. These reason because it shows the value of the critical ratio that is above 1.96 and the probability value $(\mathrm{P})$ which is below 0.05 as in table 3 below.

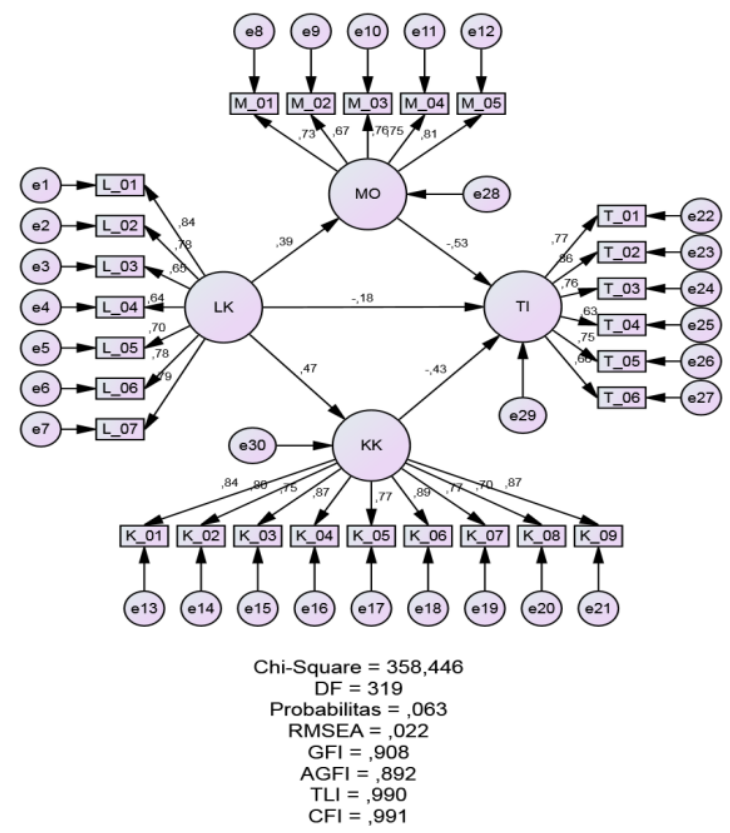

Figure 3. Testing the Research Hypothesis in the Path Diagram 
Table 3. Regression Weight Model Significance Test Results

\begin{tabular}{|l|l|l|r|r|r|r|r|}
\hline & & & Estimate & S.E. & C.R. & P & Label \\
\hline MO & $<---$ & LK &, 412 &, 076 & 5,390 & $* * *$ & \\
\hline KK & $<---$ & LK &, 517 &, 073 & 7,088 & $* * *$ & \\
\hline TI & $<---$ & MO &,- 529 &, 065 & $-8,184$ & $* * *$ & \\
\hline TI & $<---$ & KK &,- 413 &, 055 & $-7,527$ & $* * *$ & \\
\hline TI & $<---$ & LK &,- 190 &, 061 & $-3,138$ &, 002 & \\
\hline
\end{tabular}

Source: Output Amos (2020)

From results of testing the hypothesis model proposed using AMOS 22 shows that results of testing hypothesis 1 in this study indicate that variable Work Environment (LK) is positively and significantly related to variable Motivation (MO). This is evidenced by a critical ratio value of 5.390 and a probability value close to 0.00 (below 0.01 ), which is marked with $* * *$ notification. Thus the conclusion is that hypothesis 1 is accepted.

Then results of testing hypothesis 2 in this study indicate that variable working environment (LK) is positively and significantly related to variable Job Satisfaction (KK). This is evidenced by the critical ratio (CR) value of 7,088 which is above 1.96 and probability value approaching 0.00 (below 0.01 ), which is marked with $* * *$ notification.

Then results of testing hypothesis 3 in this study indicate that the Motivation (MO) variable is negatively and significantly related to variable Turnover Intention (IT). This is evidenced by the critical ratio value reach 8,814 meaning that it is below -1.96 and a probability value close to 0.00 (below 0.01 ) which is marked with a $* * *$ notification.

Furthermore, results of testing hypothesis 4 in this study indicate that variable Job Satisfaction $(\mathrm{KK})$ is negatively and significantly related to variable Turnover Intention (IT) variable. This is evidenced by the critical ratio value of $-7,527$ below -1.96 and the probability value of the probability value which is close to 0.00 (below 0.01 ), which is marked with a *** notification

Finally, results of testing hypothesis 5 in this study indicate that variable Work Environment (LK) is negatively and significantly related to the variable Turnover Intention (IT) variable. This is evidenced by the critical ratio value of $-3,138$ which is below -1.96 and a probability value of 0.002 which is below 0.05 . Based on the results of the hypothesis 5 test there is a probability value of 0.002 which is below the alpha value of $5 \%(0.05)$ 
In the mediation test using sobel stated that sobel test score using the sobel calculator was $-5,48718598$ that states less than from $-1,967$ so that the conclusion was that there was an indirect effect (mediation) between Work Environment variables on the Turnover Intention variable through Motivation variables. Based on this, it can be concluded that when the work environment is getting better, it will make motivation even higher, but Turnover Intention will be lower.The second sobel test results state that the sobel calculator sobel score is $-5.12859790<$ from -1.967 so that the conclusion is there is an indirect effect (mediation) between the Work Environment variables on the Turnover Intention variable through the Job Satisfaction variable. Based on this, it can be concluded that when the working environment is getting better, it will create a high Job Satisfaction too, but will make Turnover Intention lower.

\section{IV.CONCULSION}

Based on the results of data processing and analysis of the entire research data, we can get conclusions that can be obtained are as follows:

1. Work environment variables have a positive effect on motivation variables. The results of testing hypothesis 1 in this study indicate that the Work Environment (LK) variable is positively and significantly related to the Motivation variable (MO). Based on this it can be concluded that, this shows that if the Work Environment (LK) is increasing, it will increasingly increase Motivation (MO), and vice versa.

2. Work environment variables have a positive effect on job satisfaction variables. Hypothesis 2 test results in this study indicate that the Work Environment (LK) variable is positively and significantly related to the Job Satisfaction variable (KK). Based on this it can be concluded that, this shows that if the Work Environment (LK) is increasing, it will increasingly increase Work Satisfaction $(\mathrm{KK})$, and vice versa.

3. Motivation variables negatively affect the Turnover Intention variable. Hypothesis 3 test results in this study indicate that the Motivation (MO) variable is negatively and significantly related to the Turnover Intention (IT) variable. Based on this it can be concluded that, if the variable Motivation (MO) is increasing, it will further reduce Turnover Intention (IT) on employees, and vice versa.

4. The Job Satisfaction variable has a negative effect on the Turnover Intention variable. Hypothesis 4 test results in this study indicate that the variable Job Satisfaction (HH) is negatively and significantly related to the Turnover Intention (IT) variable. Based on this it can be concluded that, if the variable Job Satisfaction (KK) is increasing, it will further reduce Turnover Intention (IT) on employees, and vice versa.

5. Work Environment Variable (LK) has a negative effect on Turnover Intention variable. Hypothesis 5 test results in this study indicate that the Work Environment (LK) variable is negatively and significantly related to the Turnover Intention (IT) variable. Based on this it can be concluded that, if the variable 
Work Environment (LK) is increasing, it will further reduce Turnover Intention (IT) on employees, and vice versa.

6. Work Environment Variables negatively affect the Turnover Intention variable through the Motivation variable. The results of testing hypothesis 6 in this study indicate that the Work Environment (LK) variable is negatively and significantly related to the Turnover Intention (IT) variable through the Motivation variable (MO). This means that there is a mediation relationship between the work environment and Turnover Intention through motivation.

7. Work Environment Variables have a negative effect on variables on Turnover Intention through Work satisfaction variables. Hypothesis 7 test results in this study indicate that the Work Environment (LK) variable is negatively and significantly related to the Turnover Intention (IT) variable through the Job Satisfaction variable. This means that there is a mediation relationship between the work environment and Turnover Intention through means that there is a mediation relationship between the work environment and Turnover Intention through motivation. 


\section{REFERENCES}

[1] Wicaksono, Gerardus Cahyu Adhi Dan Wardoyo, P. (2017). Job Satisfaction \& Job Environment: Pengaruhnya Terhadap Intention Turnover Di Semarang Medical Center Telogorejo. Jurnal Riset Ekonomi Dan Bisnis, 10, No 1(Issn : 1979-4800), 1-16.

[2] Sugiyono. (2017). Metode Penelitian Kuantitatif, Kualitatif, Dan R\&D. Bandung: Alfabeta.

[3] Jehanzeb, K., Rasheed, A., \& Rasheed, M. F. (2013). Organizational Commitment And Turnover Intentions : Impact Of Employee' S Organizational Commitment And Turnover Intentions: Impact Of Employee' S Training In Private Sector Of Saudi Arabia. International Journal Of Business And Management, Vol 8 No 8 (Issn 1833-3850 E-Issn 1833-8119). Https://Doi.Org/10.5539/Ijbm.V8n8p79

[4] Healy, K.L., Sanders, M.R,.., \& Lyer, A. (2015). Parenting practices, children's peer relationships and being bullied at school. Journal of Child and Family Studies, 24(1), 127-140. DOI: 10.1007/ s10826-0139820-4.

[5] Hair Et Al. (2011). Multivariate Data Analysis (7th Ed.). New Jersey: Pearson Prentice Hall.

[6] A.A. Anwar Prabu Mangkunegara. (2011). Manajemen Sumber Daya Manusia Perusahaan. Bandung: Rosda.

[7] Aji, O. A., \& Budianto, T. (2015). Pengaruh Lingkungan Kerja Terhadap Kinerja Pegawai Pada PT Perusahaan Gas Negara ( Persero ) Tbk Sbu Distribusi Wilayah I Jakarta. Jurnal Ilmiah Prodi Manajemen Universitas Pamulang, 3(1).

[8] Alamsyah, N., \& Yasra, R. (2018). Analisa Pengaruh Kepuasan Kerja Dan Lingkungan Kerja Terhadap Turnover Pada Karyawan Di PT. Sanjaya Sejahtera. Jurnal Industri Kreatif (Jik), 2(1), 51. Https://Doi.Org/10.36352/Jik.V2i1.70

[9] Andreani, H. Dan. (2017). Analisis Pengaruh Motivasi Dan Kompensasi Terhadap Kinerja Karyawan Di Broadway Barbershop PT Bersama Lima Putera. Agora, 5(1), 2.

[10] Aulani, R., \& Wulanyani, N. M. S. (2017). Faktor-Faktor Kepuasan Kerja Pada Karyawan Perusahaan Perjalanan Wisata Di Denpasar. Jurnal Psikologi Udayana, 4 No 2(Issn: 2354 5607), 426-434.

[11] Aulia Putri;Stefanus Rumangkit. (2017). Pengaruh Ketidakamanan Kerja, Kepuasan Kerja Dan Motivasi Kerja Terhadap Turnover Intention Pada PT.Ratu Pola Bumi (Rpb) Bandar Lampung. Prosiding Seminar Nasional Darmajaya, (2598 - 0246 | E-Issn: 2598-0238), 229$244 . \quad$ Retrieved From Https://Jurnal.Darmajaya.Ac.Id/Index.Php/Psnd/Article/View/85

[12] Badriyah, M. (2015). Manajemen Sumber Daya Manusia. Bandung: Cv Pustaka Setia.

[13] Balboni, T. A., Balboni, M., Enzinger, A. C., Gallivan, K., Paulk, M. E., Wright, A., ... Prigerson, H. G. (2013). Provision Of Spiritual Support To Patients With Advanced Cancer By Religious Communities And 
Associations With Medical Care At The End Of Life. Jama Internal Medicine, 173(12), 1109-1117.

Https://Doi.Org/10.1001/Jamainternmed.2013.903

[14] Cahyanto, B., \& Utama, I. (2016). Pengaruh Komunikasi Organisasi Dan Lingkungan Kerja Terhadap Kepuasan Kerja Pada PT. Cakra Tranports Utama Jimbaran, Bali. E-Jurnal Manajemen Universitas Udayana, 5(5), 3248-3273.

[15] Dewi, K., \& Wibawa, I. (2016). Pengaruh Stres Kerja Pada Turnover Intention Yang Dimediasi Kepuasan Kerja Agen Ajb Bumiputera 1912. E-Jurnal Manajemen Universitas Udayana, 5(6), 3560-3588.

[16] Erni Hayati Nasution. (2018). Faktor-Faktor Yang Mempengaruhi Kepuasan Kerja Dan Dampaknya Terhadap Kinerja Pegawai Kanwil Kanwil Direktorat Jenderal Kekayaan Negara Aceh. Jurnal Magister Manajemen, 2 No 1(Issn 2302-0199), 123-134. 